\title{
Do selenium and glutathione (GSH) detoxify mercury in marine invertebrates? Effects on lysosomal response in the tropical blood clam Anadara granosa
}

\author{
Joseph P. Chandy \& B. Patel \\ Health Physics Division, Bhabha Atomic Research Centre, Bombay 400085 , India
}

\begin{abstract}
Interactions of mercury, selenium and glutathione (GSH) with the lysosomal enzymes arylsulphatase and acidphosphatase in the digestive cells of the tropical blood clam Anadara granosa (L.) were studied. After $96 \mathrm{~h}$ exposure in vivo, mercury and selenium individually activated arylsulphatase to varying degrees. The latency of the enzyme also increased significantly. On exposure to a combination of mercury and selenium, total and free arylsulphatase activity was inhibited but the increase in lysosomal bound activity was significantly greater Exposure to GSH alone and in the presence of $\mathrm{Hg}$ resulted in considerable decreases in arylsulphatase activity. $\mathrm{Hg}$, Se and GSH, either alone or in combination, had no significant effect on acidphosphatase activity. In vitro inhibition of both arylsulphatase and acidphosphatase depended on concentration of mercury. Selenium inhibited acidphosphatase activity, but not that of arylsulphatase. Both arylsulphatase and acidphosphatase previously inhibited by $\mathrm{Hg}$ were completely reactivated and latency restored by GSH. Inhibition and reactivation were dependent upon concentration of $\mathrm{Hg}$ and $\mathrm{GSH}$. Bioaccumulation of $\mathrm{Hg}$ in soft tissues was increased by about $50 \%$ in clams exposed to combination of $\mathrm{Hg}$ and Se compared to clams exposed to $\mathrm{Hg}$ alone. However, uptake of $\mathrm{Hg}$ was completely $(95 \%)$ blocked by GSH. Thus, clams exposed to $\mathrm{Hg}$, Se and GSH individually and in combination showed different effects on lysosomal enzyme activity in vitro and in vivo. Unlike among vertebrate species, Se failed to provide protection against deleterious effects of $\mathrm{Hg}$ in the marine clam. Glutathione, on the other hand, unequivocally provided effective protection
\end{abstract}

\section{INTRODUCTION}

Since the 'Minamata' incident in the late 50's, studies on the impact of heavy metals, including mercury, cadmium and chromium, on the health of aquatic ecosystems have received wide attention (Kurland et al. 1960, Johnels et al. 1967, Goldberg 1980, Ray 1984, Patel et al. 1985a, b). The increased load on natural mechanisms of detoxification and disposal has allowed these elements to accumulate in the near-shore environment around industrial and sewage disposal areas. Benthic invertebrates, especially molluscs, are found to concentrate a variety of heavy metals, including $\mathrm{Hg}$, from their environment by several orders of magnitude above ambient levels (Leonzio et al. 1981, Roesijadi et al. 1981). The kinetics of uptake and bioaccumulation of metallic elements are essentially controlled by their chemical forms and abundance in the environmental matrices - water, sediment and food. Many of these elements are not biologically essential and are toxic at elevated concentrations. Marine invertebrates seem to possess some biochemical mechanisms to sequester and accumulate these metals in non-toxic forms. De novo synthesis of sulphydryl-rich low molecular weight proteins on induction by a variety of metals such as $\mathrm{Hg}, \mathrm{Cu}, \mathrm{Cd} \& \mathrm{Zn}$ has implied a detoxification function for these metallothioneins (Webb 1975, Bremner \& Young 1976, Olafson et al. 1979, Magos \& Webb 1980, Ray \& White 1981, Roesijadi \& Hall 1981, Eaton \& Toal 1983). At the cellular level, cytosomes and lysosomes are important in the uptake, sequestration and bioaccumulation of various metals (Fowler et al. 1975, Lowe \& Moore 1979, Chassard-Bouchaud 1983, George 1983).

The lysosomal system has been shown to be very sensitive to changes in the intra- and extracellular 
environment, and subsequently to be involved, directly or indirectly, in controlling many physiological and pathological processes. Interactions of many heavy metals, including $\mathrm{Hg}$, with lysosomal systems have been reported among vertebrate species (Sternlieb \& Goldfischer 1976). Mercury has been demonstrated as a lysosomal inclusion in rat liver following its injection (Norseth 1968). The incorporated Hg has been shown to have an inhibitory effect on lysosomal acidphosphatase and $\beta$-glucuronidase (Chavapil et al. 1972, Hinton \& Koenig 1975). The integrity of lysosomal membranes has also been reported to be adversely affected by $\mathrm{Hg}$, resulting in subsequent release of acid hydrolytic contents into the cytoplasm (Verity \& Reith 1967, Lauwerys \& Buchet 1972). Increase or decrease in the lysosomal enzyme activity depending upon the concentrations of $\mathrm{Hg}$ administered has been shown in vivo (Taylor 1965, Hinton \& Koenig 1975). A similar association between lysosomal systems and heavy metals has also been reported in marine lamellibranchs, especially in the mussel Mytilus edulis (Moore 1977, Lowe \& Moore 1979, George et al. 1982).

The coaccumulation of $\mathrm{Hg}$ and $\mathrm{Se}$ in tissues of fishes and mammals is well established (Renzoni 1982). The bioaccumulation of these 2 metal ions in a molar ratio near 1 in marine fishes and mammals, including man, has been found to show antagonistic effects. Furthermore, Se has been found to offer protection against the adverse effects of $\mathrm{Hg}$ (Bernhard \& Renzoni 1977). In the field of interactions of trace elements, the example of mutual antagonism of $\mathrm{Hg}$ and Se has been cited as a rule rather than an exception. Glutathione peroxidase, a selenoprotein enzyme, is also reported to decrease the toxic effects of methylmercury by securing the integrity of cell components by antioxidation (Chang \& Suber 1982). Se has also been shown to reduce the incidence of tumour formation by different carcinogens (Shamberger 1981). Similarly sulphydryl-rich compounds such as reduced glutathione (GSH) and cysteïne can reverse the inhibitory effects of $\mathrm{Hg}$ on lysosomal enzymes (Doyle et al. 1955, Verity \& Reith 1967). However, evidence of such a protective role of selenium or its detoxifying effects for $\mathrm{Hg}$ in marine invertebrates is rather fragmentary. The studies presented here were, therefore, designed to understand and evaluate the possible effects of $\mathrm{Hg}$ on 2 lysosomal marker enzymes, acidphosphatase and arylsulphatase, in the digestive cells of the tropical burrowing blood clam Anadara granosa. These studies continue those by Patel \& Patel (1985), which discuss the effect of environmental parameters on the lysosomal marker enzymes and suggest the monitoring of lysosomal latency as a pollution index. The species was selected since it is extensively harvested and found to be an 'ideal indicator' to detect the presence of many pollutants (Patel \& Patel 1982, Patel et al. 1985a). The possible protective and/or detoxifying effect provided by Se and GSH against that of $\mathrm{Hg}$ on both lysosomal enzymes in this species is also discussed.

\section{EXPERIMENTAL PROTOCOL}

About 100 arcid clams Anadara granosa (L.), 3 to 4 $\mathrm{cm}$ in shell length, were collected from the intertidal zone off Trombay (Bombay) during spring low tide periods. Extraneous matter was removed by gentle scrubbing. Clams were then acclimated to the laboratory environment for a period of $24 \mathrm{~h}$, at a salinity of about $33 \mathrm{ppt}$, at $25 \pm 2{ }^{\circ} \mathrm{C}$, and dissolved oxygen around $6.0 \mathrm{mg} \mathrm{l}^{-1}$.

A static bioassay technique was followed. A group of 10 clams in a glass aquarium (5 1 capacity) was exposed to mercury (as $\mathrm{HgCl}_{2}$ ) at $0.1 \mathrm{mg} \mathrm{l}^{-1}$, selenium (as $\mathrm{SeO}_{2}$ ) at $1.0 \mathrm{mg} \mathrm{l}^{-1}$ and reduced glutathione (GSH) at $1.0 \mathrm{mg} \mathrm{l}^{-1}$ concentration for a period of $96 \mathrm{~h}$. A control group was maintained without any addition of chemicals. Bleeding and moribund animals, if any, were removed, and the aquarium water was replaced by freshly collected filtered (Whatman No. 42) sea water in the morning and evening, with appropriate addition of fresh chemicals to maintain static concentrations.

Separate sets of experiments were performed to study the combined effects of Se with $\mathrm{Hg}$ and $\mathrm{GSH}$ with $\mathrm{Hg}$. In this series of experiments, a group of 10 clams each was exposed to a combination of $1.0 \mathrm{mg} \mathrm{l}^{-1}$ Se and $0.1 \mathrm{mg} \mathrm{l}^{-1} \mathrm{Hg}$ and another group to $1.0 \mathrm{mg} \mathrm{l}^{-1}$ GSH and $0.1 \mathrm{mg} \mathrm{l}^{-1} \mathrm{Hg}$, for $96 \mathrm{~h}$. A control group was maintained without any addition. No attempt was made to feed the clams during the exposures. On completion of $96 \mathrm{~h}$ exposure, clams from all groups were sacrificed and soft tissue dissected out.

Determination of acidphosphatase (E.C.3.1.3.2) and arylsulphatase (E.C.3.1.6.1) activity. Digestive glands (hepatopancreas/midgut gland) from half the population of Anadara granosa from the exposed and unexposed (=control) groups were separated from the visceral mass in a crushed-ice bath. Details of tissue preparation and optimisation of the enzyme assays followed during the present studies are the same as those described by Patel \& Patel (1985). The digestive gland was homogenized in $10 \mathrm{vol}(\mathrm{w} / \mathrm{v}) 0.25 \mathrm{M}$ sucrose, $\mathrm{pH} 7.2$, with 5 up and down strokes at 500 rpm using a teflon pestle. Appropriate dilutions were made and the acidphosphatase and arylsulphatase activity in the homogenate estimated. Percent latent (lysosomalbound) enzyme activity was calculated from the differences between the levels of activity observed in assays 
conducted with ('total activity') and without ('free activity') the addition of the non-ionic detergent Triton $\mathrm{X} 100$ during the enzyme preparation (Patel \& Patel 1985),

In order to study the effects of different chemicals in vitro, $1 \mathrm{mg}$ of the digestive gland homogenate of freshly collected clams was incubated with the desired concentration of $\mathrm{Hg}$, Se and $\mathrm{GSH}$ or with mixtures of $\mathrm{Se}$ and $\mathrm{Hg}$ or $\mathrm{GSH}$ and $\mathrm{Hg}$, for 5 min at room temperature, before estimating the enzyme activity. To evaluate the effect of $\mathrm{Hg}$ and incubation time on enzyme activity, the homogenates were incubated with appropriate concentrations of $\mathrm{Hg}$ for 5 to $120 \mathrm{~min}$. Furthermore, the homogenates were treated with Se or GSH both before and after $\mathrm{Hg}$ addition to ascertain whether pre- or post-treatment made any difference to the inhibition or reactivation of these enzymes.

The enzyme assays were conducted at $25 \pm 2{ }^{\circ} \mathrm{C}$. The levels of enzyme activity are expressed in 'international enzyme units' (I.U.) defined as the amount of enzyme required to liberate $1 \mu \mathrm{mol}$ of product per minute per gram tissue. Levels of protein in the tissue homogenates were estimated by a standard Biuret method (Gornall et al. 1949).
Estimation of tissue mercury. The soft tissues of the remaining population of clams after $96 \mathrm{~h}$ exposure to various concentrations were removed, pooled, then homogenized and lyophilized. About 1 to $2 \mathrm{~g}$ lyophilized tissue was digested $\left(\mathrm{HNO}_{3}: \mathrm{H}_{2} \mathrm{SO}_{4} ; 5: 1\right)$ in a Bethge apparatus. Blanks were also run along with the samples. Total $\mathrm{Hg}$ in the digest was estimated by flameless atomic absorption spectrometry. The instrument was calibrated using $\mathrm{HgCl}_{2}$. All samples were analysed in duplicate.

\section{RESULTS}

\section{Effects on lysosomal enzymes}

\section{In vivo}

Arylsulphatase. The effect of $\mathrm{Hg}$, Se and GSH on arylsulphatase activity in the digestive gland of Anadara granosa after $96 \mathrm{~h}$ exposure is shown in Table 1. Table 2 shows the statistical significance (Student's t test) in the changes in enzyme activity between treatments. Mean arylsulphatase activity was $22.8 \pm 6.9$ IU

Table 1. Anadara granosa. Effect of mercury $\left(0.1 \mathrm{mg} \mathrm{l}^{-1}\right)$, selenium $\left(1.0 \mathrm{mg} \mathrm{l}^{-1}\right)$ and reduced glutathione (GSH) (1.0 mg $\left.\mathrm{l}^{-1}\right)$ on arylsulphatase activity in the digestive gland of the blood clam after $96 \mathrm{~h}$ exposure under laboratory conditions. Figures in parenthesis denote percent increase $(+)$ or decrease $(-)$ in enzyme activity in exposed animals compared to controls

\begin{tabular}{|lcccc|}
\hline \multicolumn{1}{|c}{ Treatment } & $\begin{array}{c}\text { No. of } \\
\text { experiments } \\
(\mathrm{n})\end{array}$ & Total & \multicolumn{2}{c|}{$\begin{array}{c}\text { Mean arylsulphatase activity (IU } \pm \text { SD) } \\
\text { Free Latency } \\
\text { (particle-bound) }\end{array}$} \\
\hline Control & 12 & $22.8 \pm 6.9$ & $16.9 \pm 6.2$ & $25.9 \pm 7.1$ \\
Mercury & 12 & $33.7 \pm 8.3(+49)$ & $24.5 \pm 4.8(+45)$ & $34.3 \pm 9.9(+33)$ \\
Selenium & 6 & $42.0 \pm 11.0(+84)$ & $26.2 \pm 4.3(+55)$ & $45.3 \pm 4.8(+75)$ \\
Glutathione & 6 & $14.0 \pm 2.3(-39)$ & $12.2 \pm 2.2(-28)$ & $15.0 \pm 2.8(-42)$ \\
Mercury \& selenium & 6 & $16.4 \pm 2.1(-28)$ & $10.8 \pm 3.7(-36)$ & $35.3 \pm 5.6(+36)$ \\
Mercury \& glutathione & 6 & $14.0 \pm 1.8(-39)$ & $12.2 \pm 1.6(-28)$ & $12.9 \pm 2.1(-50)$ \\
\hline
\end{tabular}

Table 2. Statistical analysis of the data presented in Table 1 in terms of significance (Student's t test) between treatments. NS: not significant at 0.05 level. $(+)$ denotes increase and $(-)$ decrease in enzyme activity (Table 1)

\begin{tabular}{|c|c|c|c|}
\hline \multirow[t]{2}{*}{ Between treatments: } & \multicolumn{3}{|c|}{ 'P' value (arylsulphatase activity) } \\
\hline & Total & Free & $\%$ Latency \\
\hline Control - mercury (0.1 $\mathrm{mg} \mathrm{l}^{-1}$ ) & $0.001(+)$ & $0.01(+)$ & $0.02(+)$ \\
\hline Control - selenium $\left(1.0 \mathrm{mg} \mathrm{l}^{-1}\right)$ & $0.001(+)$ & 0.02 & 0.001 \\
\hline Control - mercury \& selenium & NS & NS & 0.02 \\
\hline Mercury - selenium & NS & 0.01 & NS \\
\hline Mercury - mercury \& selenium & $0.001(-)$ & 0.001 & NS \\
\hline Selenium - mercury \& selenium & $0.01(-)$ & 0.001 & NS \\
\hline Control - glutathione $\left(1.0 \mathrm{mg} \mathrm{l}^{-1}\right)$ & $0.02(-)$ & NS & 0.01 \\
\hline Mercury - glutathione & $0.001(-)$ & 0.001 & 0.01 \\
\hline Mercury - mercury \& glutathione & $0.001(-)$ & 0.001 & 0.01 \\
\hline Glutathione - mercury \& glutathione & NS & NS & NS \\
\hline
\end{tabular}


(total activity) and 16.9 \pm 6.2 IU (free activity) $(n=12)$ in the digestive cells of freshly collected clams and of clams acclimated under laboratory conditions for $96 \mathrm{~h}$. On exposure to $\mathrm{Hg}\left(0.1 \mathrm{mg} \mathrm{l}^{-1}\right)$ both total and free enzyme activity increased significantly by at least $45 \%$ ( $\mathrm{P}>0.01)$. The percent latency of the lysosomal fraction of the enzyme also increased significantly $(+33 \%$, Table 1). Following $96 \mathrm{~h}$ exposure to Se 1.0 $\left.\mathrm{mg} 1^{-1}\right)$ the total activity $(+84 \%)$, free activity $(+55 \%)$, and lysosomal latency $(+75 \%)$ also increased. This then indicates that the presence of Se not only increased the free enzyme activity but also stimulated the lysosomal-bound activity significantly (Tables $1 \& 2$ ). On exposure to GSH ( $1.0 \mathrm{mg} \mathrm{l}^{-1}$ ), on the other hand, total enzyme activity decreased considerably $(-39 \%$. Table 1$)$. However, the decrease in free activity ( $-28 \%$ ) was not statistically significant (Table 2 ). The differences between total and free enzyme activity in clams exposed to combinations of $\mathrm{Hg}$ and $\mathrm{Se}$ and clams exposed to these elements individually are found to be highly significant (Table 2). The latency of the lysosomal fraction, however, was not significantly affected when compared to the group exposed to $\mathrm{Hg}$ alone. The percent increase in lysosomal latency observed on exposure to $\mathrm{Se}(+75 \%)$ or $\mathrm{Hg}(+33 \%)$ individually if considered purely on additive basis $(107 \%)$ was found to be significantly smaller $(36 \%)$ in the group exposed to the combination of both elements. On exposure to $\mathrm{Hg}$ in the presence of GSH, the increase in the enzyme activity in groups exposed to $\mathrm{Hg}$ alone completely reversed. Enzyme activity in these clams remained practically the same as that in clams exposed to GSH alone (Table 1). This clearly demonstrates that the presence of GSH, unlike that of $\mathrm{Se}$, either completely blocked the entry of $\mathrm{Hg}$ into the system or prevented the adverse effects of $\mathrm{Hg}$ through forming some biochemical complex(es) and thereby providing protection.

Acidphosphatase. Table 3 records the impact of all 3 chemicals, individually or in combination, on acidphosphatase activity in the digestive cells of the arcid clam. No significant differences were evident compared to unexposed control animals.

\section{In vitro}

Arylsulphatase. Both total and free arylsulphatase activity in vitro was inhibited by $\mathrm{Hg}$, in contrast to results observed in vivo. The percent inhibition was dependent upon the $\mathrm{Hg}$ concentration as depicted in Fig. 1. The $\mathrm{EC}_{50}$ (effective concentration to yield $50 \%$ activity) was found to be around $8 \mu \mathrm{g} \mathrm{Hg} \mathrm{mg}^{-1}$ tissue (Fig. 1): about $52 \%$ inhibition occurred within 5 min of

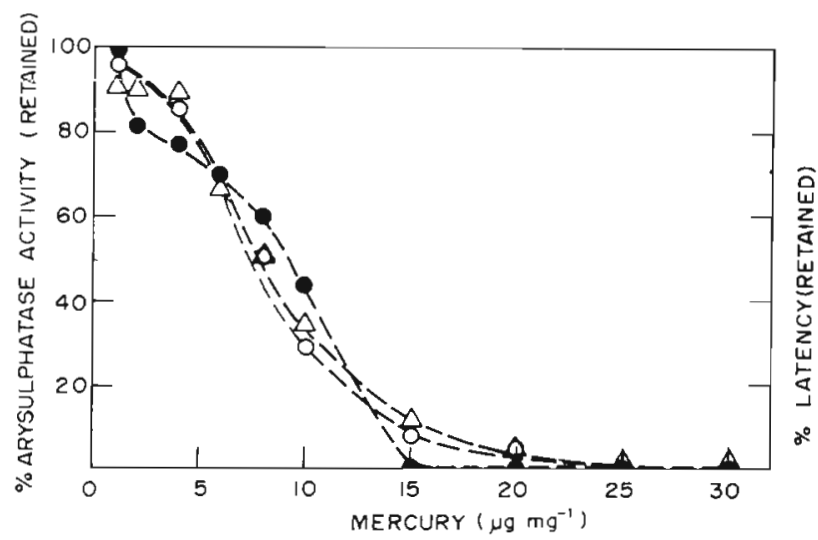

Fig. 1. Anadara granosa. Effect of mercury $\left(\mathrm{HgCl}_{2}\right)$ on total, free and latent arylsulphatase activity in digestive cells in vitro expressed as percent of the control. (O) Total; $(\Delta)$ free; (•) latent

incubation in the presence of $8 \mu \mathrm{g} \mathrm{Hg} \mathrm{mg}^{-1}$. Further increase in the incubation period upto $2 \mathrm{~h}$, however, did not show any further increase in the enzyme inhibition. Latent enzyme activity decreased by $40 \%$ on addition of $8 \mu \mathrm{g} \mathrm{Hg}$ to the reaction mixture (Fig. 1). Almost all this particle-bound activity was released on addition of $15 \mu \mathrm{g} \mathrm{Hg} \mathrm{mg}^{-1}$ tissue, suggesting complete labilization of the lysosomes.

Fig. 2 records the effect of Se on arylsulphatase

Table 3. Anadara granosa. Acidphosphatase activity in the digestive cells of the blood clam after 96 h exposure to mercury $\left(0.1 \mathrm{mg} \mathrm{l} \mathrm{m}^{-1}\right)$, selenium $\left(1.0 \mathrm{mg} \mathrm{^{-1 }}\right)$, and glutathione $\left(1.0 \mathrm{mg} \mathrm{l}^{-1}\right)$ under laboratory conditions. The increases in activity were too small to be statistically significant

\begin{tabular}{|lccr|}
\hline Treatment & $\begin{array}{c}\text { Number of } \\
\text { experiments }\end{array}$ & $\begin{array}{c}\text { Acidphosphatase } \\
\text { activity (IU } \pm \text { SD) }\end{array}$ & $\begin{array}{c}\text { \% Increase } \\
\text { over control }\end{array}$ \\
\hline Control & 12 & $1.50+0.21$ & +14.0 \\
Mercury & 12 & $1.71+0.20$ & +2.8 \\
Selenium & 6 & $1.54+0.20$ & +12.0 \\
Glutathione & 6 & $1.68+0.13$ & 0.6 \\
Mercury \& selenium & 6 & $1.51+0.21$ & +10.7 \\
Mercury \& glutathione & 6 & $1.66+0.09$ & + \\
\hline
\end{tabular}


activity in vitro. Incubation of the homogenate with $\mathrm{Se}$ in the range 2 to $200 \mu \mathrm{g} \mathrm{mg}^{-1}$ tissue did not show any significant changes in arylsulphatase activity, unlike those observed on addition of $\mathrm{Hg}$ alone. Similarly, addition of Se within the range 2 to $50 \mu \mathrm{g} \mathrm{mg}^{-1}$ tissue in the presence of $8 \mu \mathrm{g} \mathrm{Hg}$ did not show any appreciable change in the inhibitory effect of $\mathrm{Hg}$ (Fig, 2). This

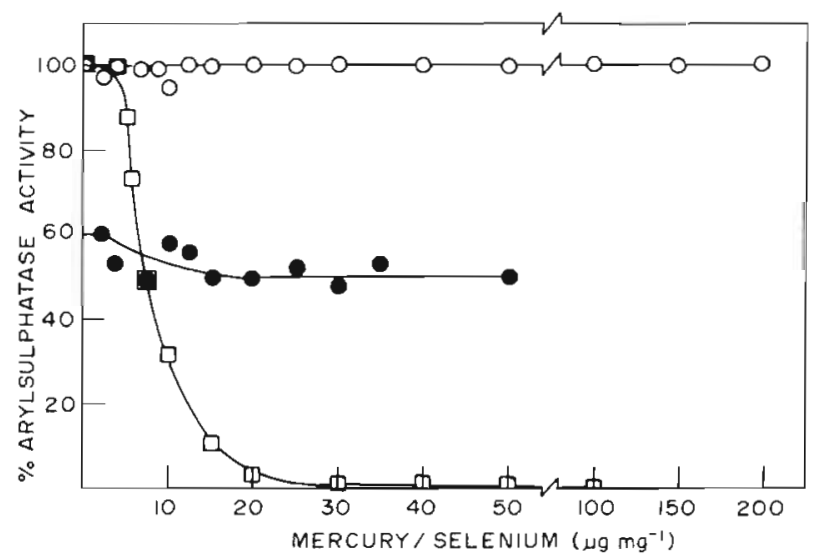

Fig. 2. Anadara granosa. Effect of selenium $\left(\mathrm{SeO}_{2}\right)$ and mercury on arylsulphatase activity in digestive cells in vitro expressed as percent of the control. (O) Selenium; ( $\square$ ) mercury;

(•) mercury + selenium

confirms in vivo observations that Se neither blocked the entry of $\mathrm{Hg}$ nor prevented its effect when added simultaneously to the homogenate.

The effect of $\mathrm{Hg}$ in the presence of GSH on the arylsulphatase activity in the hepatic cells of Anadara granosa in vitro is shown in Table 4 . It will be seen that on addition of $\mathrm{Hg}$, both total and free activity decreased, by 24 and $40 \%(5.0 \mu \mathrm{g} \mathrm{Hg})$ and 75 and $71 \%$ (25 $\mu \mathrm{g} \mathrm{Hg}$ ) respectively. The addition of GSH in the range 0.1 to $10 \mathrm{mM}$, however, reactivated both free and total enzyme activity considerably. Thus total enzyme activity in the homogenate treated with $5 \mu \mathrm{g} \mathrm{Hg}$ increased from 76 to $100 \%$ on addition of GSH 10.5 $\mathrm{mM}$ ). In the presence of $25 \mu \mathrm{g} \mathrm{Hg}$, reactivation of the

Table 4. Anadara granosa. Reactivation of mercury-inhibited arylsulphatase activity in the digestive gland as a function of addition of glutathione (reduced) in vitro. Values are \% of arylsulphatase activity in controls. Average of 5 experiments. $\mathrm{SD}$ in each enzyme assay did not exceed $10 \%$

\begin{tabular}{|c|c|c|c|c|c|c|}
\hline \multirow{2}{*}{$\begin{array}{l}\text { Mercury } \\
\left(\mu \mathrm{g} \mathrm{mg}^{-1}\right)\end{array}$} & \multirow{2}{*}{$\begin{array}{l}\text { Arylsulphatase } \\
\text { activity }\end{array}$} & \multicolumn{5}{|c|}{ Glutathione ( $\mathrm{mM}$ ) } \\
\hline & & 0.0 & 0.1 & 0.5 & 1.0 & 10.0 \\
\hline \multirow[t]{2}{*}{5.0} & Total & 76 & 89 & 100 & 100 & 100 \\
\hline & Free & 60 & 88 & 100 & 100 & 100 \\
\hline \multirow[t]{2}{*}{25.0} & Total & 25 & 39 & 72 & 90 & 100 \\
\hline & Free & 29 & 38 & 67 & 85 & 100 \\
\hline
\end{tabular}

enzyme activity from 25 to $100 \%$ was achieved gradually on step-by-step addition of higher quantities of GSH (0.5 to $10 \mathrm{mM}$ ) (Table 4). Thus, the inhibition and reactivation of arylsulphatase activity was found to be dependent upon the concentration of $\mathrm{Hg}$ and $\mathrm{GSH}$ respectively. The sequence of addition of $\mathrm{GSH}_{\text {, either }}$ before or after the $\mathrm{Hg}$ treatment, however, did not influence the biochemical processes involved in the reactivation of the enzymes and/or stabilization of the lysosomal structure. This then clearly demonstrates that unlike Se, GSH not only offered protection against the Hg effect, but also almost prevented its impact and stabilized the lysosomes.

Acidphosphatase. The acidphosphatase activity in the digestive-gland homogenate of Anadara granosa was inhibited appreciably on addition of $\mathrm{Hg}$. The percent inhibition was also dependent upon the $\mathrm{Hg}$ concentration added (Fig. 3). The $\mathrm{EC}_{50}$ for acidphosphat-

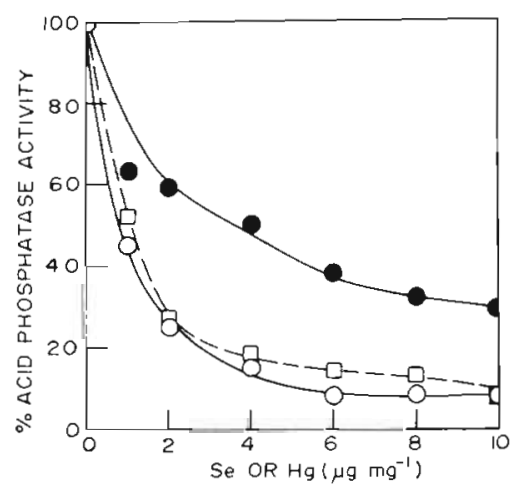

Fig. 3. Anadara granosa. Effects of selenium and mercury on acidphosphatase activity in digestive cells in vitro expressed as percent of the control. (•) Selenium; ( $\square$ ) mercury; (O) mercury + selenium

ase was about $1 \mu \mathrm{g} \mathrm{Hg} \mathrm{mg} \mathrm{mg}^{-1}$ tissue which is around $88 \%$ lower than that observed in the case of arylsulphatase $(8 \mu \mathrm{g})$. Furthermore, the inhibitory effect of $\mathrm{Hg}$ on the acidphosphatase was complete within the initial 5 min of incubation. Further exposure upto $2 \mathrm{~h}$, however, did not change the initial impact observed.

Se also inhibited acidphosphatase activity, the inhibition being concentration-dependent (Fig. 3). The $\mathrm{EC}_{50}$ for Se was about $4 \mu \mathrm{g} \mathrm{mg}^{-1}$ tissue (Fig. 3). Results on reactivation of $\mathrm{Hg}$-inhibited acidphosphatase by GSH are recorded in Table 5. Enzyme activity (total) was inhibited by 50 and $80 \%$ respectively on addition of 1 and $3 \mu \mathrm{g} \mathrm{Hg}$ (Table 5). On addition of 0.1 to $0.5 \mathrm{mM}$ GSH the reduction caused by the addition of $1 \mu \mathrm{g} \mathrm{Hg}$ was restored to near control levels. Enzyme activity which had decreased to $20 \%$ on addition of $3 \mu \mathrm{g} \mathrm{Hg}$ increased to $100 \%$ gradually on addition of GSH $(0.1$ to $10.0 \mathrm{mM}$ ). 
Table 5. Anadara granosa. Reactivation of mercury-inhibited acidphosphatase activity (total) in the digestive cells as a function of glutathione in vitro. Values are \% of acidphosphatase activity in controls. Average of 5 experiments. SD in each assay did not exceed $10 \%$

\begin{tabular}{|c|c|c|c|c|c|}
\hline \multirow[t]{2}{*}{ Mercury ( $\mu \mathrm{g} \mathrm{mg}^{-1}$ tissue) } & \multicolumn{5}{|c|}{ Glutathione (mM) } \\
\hline & 0.0 & 0.1 & 0.5 & 1.0 & 10.0 \\
\hline 1.0 added before GSH treatment & 52.0 & 76.0 & 100 & 100 & 100 \\
\hline 1.0 added after GSH treatment & 51.0 & 78.0 & 100 & 100 & 100 \\
\hline 3.0 added before GSH treatment & 20.0 & 21.0 & 29.0 & 51.0 & 100 \\
\hline 3.0 added after GSH treatment & 20.0 & 24.0 & 34.0 & 52.0 & 100 \\
\hline
\end{tabular}

\section{Protein content}

Protein content in the digestive gland of clams varied in the range 70 to $94 \mathrm{mg} \mathrm{g}^{-1}$ (mean $82.4 \pm 11.4$. $\mathrm{n}=18$ ). In the experimental groups the protein content remained unaltered within experimental error (79.4 \pm $3.0 \mathrm{mg} \mathrm{g^{-1 }}$ ). This suggests that the changes brought about in arylsulphatase and acidphosphatase activity by $\mathrm{Hg}$, Se and GSH or their combination were not due to proteolysis, but may well be due to some other intrinsic biochemical changes.

\section{Bioaccumulation of mercury}

Mercury concentration in soft tissues of Anadara granosa from the natural environment at ambient seawater levels $\left(0.13\right.$ to $\left.0.25 \mu \mathrm{g} \mathrm{l}^{-1}\right)$ ranged from 0.54 to $1.46 \mu \mathrm{g} \mathrm{g}^{-1}$ dry tissue (average: $0.94 \pm 0.4$ ). In the groups exposed to $\mathrm{Se}$ and $\mathrm{GSH}, \mathrm{Hg}$ levels also fit within this range (Table 6). At the end of $96 \mathrm{~h}$ exposure

Table 6. Anadara granosa. Bioaccumulation of mercury in the soft parts, after $96 \mathrm{~h}$ exposure to mercury $\left(0.1 \mathrm{mg} \mathrm{l}^{-1}\right)$ selenium $\left(1.0 \mathrm{mg} \mathrm{l}^{-1}\right)$ or glutathione $\left(1.0 \mathrm{mg} \mathrm{l}^{-1}\right)$. Figures in parenthesis denote number of estimations. NS: not significant at 0.05 level

\begin{tabular}{|c|c|c|}
\hline \multirow[t]{2}{*}{ Treatment } & \multicolumn{2}{|c|}{ Bioaccumulation } \\
\hline & $\begin{array}{c}\text { Mercury } \\
\left(\mu g g^{-1}\right) \\
\pm \mathrm{SD}\end{array}$ & $\begin{array}{c}\text { 'P' value } \\
\text { between } \\
\text { treatments }\end{array}$ \\
\hline A. Control & $\begin{array}{c}0.94 \pm 0.4 \\
(20)\end{array}$ & - \\
\hline B. Mercury & $25.1 \pm 3.9$ & $(A \& B) 0.001$ \\
\hline C. Selenium & $\begin{array}{c}0.92 \pm 0.1 \\
(5)\end{array}$ & $(A \& C) N S$ \\
\hline D. Glutathione & $0.74 \pm 0.3$ & $(A \& D) N S$ \\
\hline E. Mercury \& selenium & $\begin{array}{c}37.9 \pm 4.0 \\
(5)\end{array}$ & (B \& E) 0.001 \\
\hline F. Mercury \& glutathione & $1.8 \pm 0.2$ & $(A \& F) N S$ \\
\hline
\end{tabular}

to $\mathrm{Hg}\left(0.1 \mathrm{mg} \mathrm{l}^{-1}\right)$, the tissue $\mathrm{Hg}$ concentration increased to $25.1 \pm 3.9 \mu \mathrm{g} \mathrm{g}^{-1}$. Uptake was enhanced appreciably $(\sim 50 \%)$ in the group exposed to a mixture of $\mathrm{Hg}$ and Se. The tissue $\mathrm{Hg}$ content in this group rose to $37.9 \pm 4.0 \mu \mathrm{g} \mathrm{g}^{-1}$. On the other hand, after $96 \mathrm{~h}$ exposure to $\mathrm{Hg}$ in the presence of GSH, clams accumulated only about $1.8 \pm 0.2 \mu \mathrm{g} \mathrm{Hg} \mathrm{g}^{-1}$, i.e. not significantly more than that observed in the natural (control) population (Table 7). This further supports the suggestion given above that GSH almost completely blocks the entry of $\mathrm{Hg}(\sim 95 \%)$ in this species.

\section{DISCUSSION}

One of the basic biochemical properties of lysosomes is the structure-linked latency of their hydrolytic enzymes. This appears to be the direct consequence of impermeability of the lysosomal membrane to many substrates, as well as the internal membrane-bound nature of many enzymes, which render them inactive. A wide variety of xenobiotics including aromatic carcinogens, heavy metal ions and radionuclides are sequestered and accumulated by lysosomes (Koenig 1963, Allison 1969, Lowe \& Moore 1979, ChassardBouchaud 1983, George 1983, Patel \& Patel 1985). In many instances these agents are capable of destabilizing the lysosomal membranes with subsequent activation and release of hydrolytic enzymes if the storage capacity is overloaded (Moore et al. 1978). However, an increase in the size and number of lysosomes was reported in rat liver following $\mathrm{Hg}$ administration (Taylor 1965). In mussels Mytilus edulis, concentrationdependent labilization of lysosomes was observed on exposure to copper at 25 to $75 \mu \mathrm{g} \mathrm{l}^{-1}$ (Harrison \& Berger 1982). No significant reduction in lysosomal integrity was evident in the group exposed to the lowest $\mathrm{Cu}$ concentration. However, significant reduction in lysosomal latency was observed in the group exposed to the highest concentration of $\mathrm{Cu}$.

In the present studies the activities of both enzymes showed a tendency to increase on exposure of Anadara granosa to $\mathrm{Hg}$ and Se. The increase in activity was 
more dramatic in arylsulphatase than in acidphosphatase. This may well be explained in terms of transformation of both elements on entering the digestive cells into biologically inactive forms by being engulfed into the lysosomes, thereby preventing them from complexing with metabolically important molecules like enzymes. Indeed $\mathrm{Hg}$ has been demonstrated as a lysosomal inclusion in rat liver, which subsequently led to an increase in the quantity of lysosomes (Koenig 1963, Norseth 1968). This, in turn, increased the availability of hydrolytic enzymes thus enabling the system to metabolize and sequester the metal in some nontoxic form and eventually to excrete it. Nevertheless, when the load of foreign material exceeds the efficiency of the detoxifying system, the integrity of lysosomal membrane is found to be affected adversely. This may induce the activation and release of previously latent degradative enzymes, which in turn may initiate catabolism of cell components and in severe instances even the autolysis of the cell (Moore 1980). In the case of Anadara granosa exposed to $\mathrm{Hg}$ and $\mathrm{Se}_{\text {, it }}$ is presumed that metal ions that entered the digestive cells were engulfed into the lysosomal system and subsequently transformed into biologically inactive forms, suggesting that levels of $\mathrm{Hg}$ and Se were not sufficient to surpass the accumulative capacity of lysosomes as seen from the increased latent activity of the lysosomal enzymes in the clams. This assumption is corroborated by the dose-dependent labilization of lysosomes in vitro in this species.

Although total and free arylsulphatase activity in Anadara granosa exposed to a combination of $\mathrm{Hg}$ and Se decreased ( -28 and $-36 \%$ respectively), interestingly the lysosomal latency increased significantly $(+$ $36 \%$ ). This indicates that bioaccumulation of $\mathrm{Hg}$ in the tissues was sufficient to inhibit free arylsulphatase activity, possibly through complexing with enzyme/ substrate molecules, subsequently reducing the catalytic efficiency. About $50 \%$ greater bioaccumulation of $\mathrm{Hg}$ in clams exposed to a combination of $\mathrm{Hg}$ and $\mathrm{Se}$ than in those exposed to $\mathrm{Hg}$ alone suggests that an increased amount of $\mathrm{Hg}$ was available for interaction with biologically important molecules in the cell. Moreover, particle-bound activity in the controls as well as in those exposed to $\mathrm{Hg}$ in presence of $\mathrm{Se}(\sim 6.0$ I.U.) suggests that the latent enzyme was not available for interaction with $\mathrm{Hg}$. In fact, the present in vitro studies on Anadara granosa have established the relation between the amount of $\mathrm{Hg}$ present in the system and its inhibitory effect on the hydrolytic enzymes. No attempt seems to have been made to understand the possible detoxification of $\mathrm{Hg}$ and $\mathrm{Se}$ in physiological or biochemical systems of marine invertebrats in vivo and in vitro.

A very few reports are available on the combined effect of $\mathrm{Hg}$ and Se on certain physiological behaviour in marine invertebrates. In the mussel Mytilus galloprovincialis, Se uptake was reduced in the presence of $\mathrm{Hg}$. This reduction however, was not statistically significant (Fowler \& Benayoun 1976). A slight decrease (not statistically verifiable) in the $\mathrm{Hg}$ toxicity on oyster embryos was observed in the presence of Se (Glickstein 1978). Similarly, experiments with the brown mussel Perna perna have shown that a combination of Se and $\mathrm{Hg}$ resulted in a slight but consistent decrease in $\mathrm{Hg}$ toxicity in terms of rate of filtration (Watling \& Watling 1982). On the other hand, studies on the clam Scrobicularia plana provided no evidence of protection by Se against $\mathrm{Hg}$ toxicity (Langston 1981). In the present study, we found no evidence to conclude unequivocally that the 'coaccumulation of Se and $\mathrm{Hg}$ ' had antagonistic effects on the lysosomal system. In fact, coadministration of these 2 metals resulted in an increase of about $50 \%$ in the net bioaccumulation of $\mathrm{Hg}$. This observation is contrary to those made on many species of fishes and mammals. Among vertrebrates in which the coaccumulation of $\mathrm{Se}$ and $\mathrm{Hg}$ has been found, it has been suggested that the former affords natural protection against Hg toxicity (Renzoni 1982, Leonzio et al. 1982).

We are at a loss to explain the decrease observed in arylsulphatase activity in clams exposed to GSH alone and also in the presence of $\mathrm{Hg}$, since these animals did not show any symptoms of physiological stress such as increased secretion of mucus during exposure. It seems that in the group exposed to a combination of GSH and $\mathrm{Hg}$, the former neutralised the stimulatory effect of $\mathrm{Hg}$ on the enzyme and exerted its own influence reflected by a reduction in arylsulphatase activity (Table 1). Furthermore, the bioaccumulation of $\mathrm{Hg}$ in this group was almost completely inhibited $(\sim 95 \%)$. This is not surprising since GSH has also been found to prevent uptake of $\mathrm{Hg}$ in the crustaceans Artemia salina and Elminius modestus (Corner \& Rigler 1958).

Mercury is reported to inhibit a number of enzymes in vitro including lysosomal enzymes (Webb 1966, Chavapil et al. 1972). Metal ions are known to inactivate protein molecules through non-specific binding or cross-linking of essential side chains and by promoting irreversible denaturation (Ulmer 1970). Mercury dimerizes a number of single chain proteins through sulphydryl linkage. Similarly the affinity of $\mathrm{Hg}$ to sulphydryl groups exceeds that of other commonly occuring ligands to such an extent that even a large excess of these ligands does not divert sizable amounts of $\mathrm{Hg}$ from SH groups. This strong affinity is often regarded as the principal cause for the inactivation of different enzymes by $\mathrm{Hg}$. Further $\mathrm{Hg}$ is found to induce irreversible loss of structure-linked latency of the lysosomal enzymes in rat liver (Verity \& Reith 1967). During the 
present studies, we found that $\mathrm{Hg}$ and Se caused a concentration-dependent inhibition of acidphosphatase and arylsulphatase activities in vitro. The lysosomal latency of arylsulphatase decreased on incubation with elevated concentrations of $\mathrm{Hg}$. The presence of glutathione in the incubation medium almost completely prevented labilization and inhibition of the enzyme activity. Similar effective protection against $\mathrm{Hg}$ toxicity in terms of labilization of lysosomes in rat liver has also been reported (Verity \& Reith 1967). Reactivation of $\mathrm{Hg}$-inhibited $\beta$-glucuronidase, by cysteïne and to a lesser extent by versene, has also been demonstrated in Escherichia coli (Doyle et al. 1955), and confirms the importance of thiol groups in maintaining the integrity of lysosomal membranes and the latent proportion of the lysosnmal enzymes.

Although Se did not affect the activity of arylsulphatase in vitro it did inhibit that of acidphosphatase (Fig. 2 \& 3). The effects of Se and $\mathrm{Hg}$ observed in vitro during the present studies could perhaps be explained in terms of the complexation of these metal ions with enzyme and/or substrate molecules. Furthermore, unlike in vivo, wherein other protective mechanisms were found operative against metal toxicity, in vitro metal ions were freely available to interact with enzyme/substrate molecules, subsequently leading to inactivation of the enzyme. Glutathione (reduced) appeared to offer protection against $\mathrm{Hg}$ toxicity possibly by complexing with it and thereby transforming $\mathrm{Hg}$ ions into some non-toxic forms or by providing the system with additional thiol groups. Glutathione is reported to offer protection against heavy metals, which are known to destroy thiol groups, either by restoring the $\mathrm{SH}$ groups by withdrawing metal ions, or by reducing oxidised SH groups (Knox 1960).

The studies on the effects of incubation time on inhibition by $\mathrm{Hg}$ in vitro showed that the activities of both acidphosphatase and arylsulphatase were completely inhibited within 5 min of incubation. This agrees well with earlier observations using both organic and inorganic mercurials. Such rapid reaction is presumed to be the result of strong affinity of $\mathrm{Hg}$ for SH groups (Passow 1970).

It could be concluded from the present studies that the effects of $\mathrm{Hg}$ and Se in vitro and in vivo are quite different. Similarly, GSH, which was found to offer effective protection against $\mathrm{Hg}$ (when added in sufficient quantity) in vitro, also blocked the entry of $\mathrm{Hg}$ in vivo but the effect was not comparable. Exposure to individual metal ions ( $\mathrm{Hg}$ and $\mathrm{Se}$ ) has been found to have marked effects on enzymes. Similarly, the activity of both these enzymes and their lysosomal latency in the arcid clam was found to be dependent upon the physico-chemical nature of its habitat, which was influenced by the nature of pollutants present (Patel \&
Patel 1985). Clearly therefore, there is a need to understand the mechanisms involved in producing such deleterious or toxic effects by various heavy metal ions (pollutants) in combination and subsequently evolve techniques to detoxify these effects. Such information is of prime importance in maintaining the health and equilibrium of marine ecosystems exposed to different xenobiotics simultaneously.

Acknowledgements. We are greatly indebted to Dr. (Mrs) S. Patel for her unfailing help in designing experiments, especially enzyme assays, and for her suggestions. Our thanks are due to $\mathrm{Mr} \mathrm{S}$. D. Soman, Mr S. Somasundaram and Mr T. Subbaratnam for their interest. It is a pleasure to express our appreciation to Prof. David M. Taylor, Institute of Genetics and Toxicology, KFK, Karlsruhe, for his interest and suggestions. We thank Mrs A. Sant for providing techniral help The junior author (J. P. Chandy) is grateful to the Department of Atomic Energy for the award of research studentship.

\section{LITERATURE CITED}

Allison, A. C. (1969). Lysosomes and cancer. In: Dingle, J. T., Fell, H. B. (ed.) Lysosomes in biology and pathology, Vol II. North Holland/American Elsevier, Amsterdam, p. $41-68$

Bremner, I., Young, B. W. (1976). Isolation of (copper, zinc)thioneins from the livers of copper injected rats. Biochem. J. 157: $517-520$

Bernhard, M., Renzoni, A. (1977). Mercury concentration in Mediterranean marine organisms and their environment: natural or anthropogenic origin. Thalassia jugosl. 13: 265-300

Chang, L. W., Suber, R. (1982). Protective effect of selenium on methyl mercury toxicity: A possible mechanism. Bull. environ. Contam. Toxicol. 29: 285-289

Chassard-Bouchaud, C. (1983). Roles des lysosomes et des spherocristaux dans le phenomene de concentration de l' uranium chez la soule Mytilus edulis (L). Microanalyse per spectrographic des rayons X. C. r. Acad. Sci., Paris: 296: 581-586

Chavapil, M., Ryan, J. N., Brada, Z. (1972). Effects of selected chelating agents and metals on the stability of liver lysosomes. Biochem. Pharmacol. 21: 1097-1105

Corner, E. D. S., Rigler, F. H. (1958). The methods of action of toxic agents. III. Mercuric chloride and $\mathrm{N}$-amylmercuric chloride on crustaceans. J. mar. biol. Ass. U.K. 37: 85-96

Doyle, M. L., Katzman, P. A., Doisy, E. A. (1955). Production and properties of bacterial $\beta$-glucuronidase. J. biol. Chem. 217: 921-930

Eaton, D. L., Toal, B. F. (1983). A simplified method for quantitating metallothioneins in biological tissues. Sci. Total Environ. 28: 375-384

Fowler, B. A., Wolfe, D. A., Hettler, W. F. (1975). Mercury and iron uptake by cytosomes in mantle epithelial cells of quahog clams (Mercenaria mercinaria) exposed to mercury. J. Fish. Res. Bd Can. 32: 1767-1775

Fowler, S. W., Benayoun, G. (1976). Influence of environmental factors on selenium flux in two marine invertebrates. Mar. Biol. 37: 59-68

George S. G. (1983). Heavy metal detoxification in the mussel Mytilus edulis - composition of Cd-containing kidney granules (tertiary lysosomes). Comp. Biochem. Physiol. $76 \mathrm{C}: 53-57$ 
George, S. G., Coombs, T. L., Pirie, B. J. S. (1982). Characterisation of metal-containing granules from the kidney of common mussel, Mytilus edulis. Biochem. biophys. Acta. 716: $61-71$

Glickstein, N. (1978). Acute toxicity of mercury and selenium to Crassostrea gigas embryos and Cancer magister larvae. Mar. Biol. 49: 113-118

Goldberg, E. D. (ed.) (1980). The international mussel watch. National Academy of Sciences, Washington D.C

Gornall, A. G., Bardawill, C. J., David, M. M. (1949). Determination of serum protein by means of the biuret method. J. biol. Chem. 177: 751-766

Harrison, F. L., Berger, R. (1982). Effects of copper on the latency of lysosomal hexosaminidase in the digestive cells of Mytilus edulis. Mar. Biol. 68: 109-116

Hinton, D. E., Koenig, J. C. Jr. (1975). Acidphosphatase activity in subcellular fraction of fish liver exposed to methylmercuric chloride. Comp. Biochem. Physiol. 50B: 621-625

Johnels, A. G., Westermark, T., Berg, W., Persson, P. I, Sjostrand, B. (1967). Pike (Esox lucius L.) and some other aquatic organisms in Sweden as indicators of mercury contamination in the environment. Oikos 18: 323-333

Knox, W. E. (1960). Glutathione, In: Boyer P. D., Lardy, H., Myrback, K. (ed.) The enzymes. Vol. II Academic Press, New York, p. 254-271

Koenig, H. (1963). Intravital staining of lysosomes by basic dyes and metallic ions. J. Histochem. Cytochem. 11: $120-121$

Kurland, L. T., Faro, S. N., Siedler, H. (1960). Minamata disease: The outbreak of a neurological disorder in Minamata, Japan, and its relationship to the ingestion of sea food contaminated by mercuric compounds. Wld Neurol. 1: 370-395

Langston, W. J. (1981). Annual report of the council, Marine Biological Association of the United Kingdom. J. mar. biol. Ass. U.K. 61 (4): 1042

Lauwerys, R., Buchet, J. P. (1972). Study on the mechanism of lysosome labilization by inorganic mercury in vitro. Eur. $\mathrm{J}$ Biochem. 26: 535-542

Leonzio, C., Bacoi, E., Focardi, S., Renzoni, A. (1981). Heavy metals in the organisms from the northern Tyrrhenian Sea Sci. Total Environ. 20: 131-146

Leonzio, G., Focardi, S., Bacci, E. (1982). Complimentary accumulation of selenium and mercury in fish muscle. Sci. Total Environ. 24: 249-254

Lowe, D. M. Moore, M. N. (1979). The cytochemical distributions of zinc ( $\mathrm{Zn}$ II) and iron (Fe III) in the common mussel Mytilus edulis, and their relationship to lysosomes. J. mar. biol. Ass. U.K. 59: 851-858

Magos, L., Webb, M. (1980). The interactions of selenium with cadmium and mercury. CRC crit. Rev. Toxicol. 8: 1-42

Moore, M. N. (1977). Lysosomal responses to environmental chemicals in some marine invertebrates. In: Giam, C.S. (ed.) Pollution effects on marine organisms. Lexington Books, Lexington, Massachusetts, p. 143-155

Moore, M. N., Lowe, D. M., Feith, P. E. M. (1978). Lysosomal responses to experimentally injected anthracene in the digestive cells of Mytilus edulis. Mar. Biol. 48: 297-302

Moore, M. N. (1980). Cytochemical determination of cellular responses to environmental stressors in marine organisms. Rapp. p.-v. Réun. Cons. int. Explor. Mer: 179: 7-15

Norseth, T. (1968). The intracellular distribution of mercury in rat liver after a single injection of mercuric chloride. Biochem. Pharmacol. 17: 581-593
Olafson, R. W., Sim, R. G., Boto, K. G. (1979). Isolation and chemical characterisation of the heavy metal-binding protein metallothionein from marine invertebrates. Comp. Biochem. Physiol. 62B: $407-416$

Passow, H. (1970). The red blood cell: Penetration, distribution, and toxic action of heavy metals. In: Maniloff, J., Coleman, J. R., Miller, M. W (ed.) Effects of metals on cells, subcellular elements and macromolecules. Charles C. Thomas Publishers, Springfield, p. 291-340

Patel, B., Patel, S. (1982). An environmental assessment of twenty-five years of nuclear operations at Trombay - An overview. Bull. Radiation Prot. 5: 3-42

Patel, B., Patel, S. (1985). Effects of environmental parameters on lysosomal marker enzymes in the tropical blood clam, Anadara granosa L. Mar. Biol.: 85: 245-252

Patel, B., Bangera, V. S., Patel, S., Balani, M. C. (1985a). Heavy metals in the Bombay harvour area. Mar. Pollut. Bull. 16: 22-28

Patel, B., Balani, M. C., Patel, S. (1985b). Sponge 'sentinel' of heavy metals. Sci. Total Environ. 41: 143-152

Ray, S. (1984). Bioaccumulation of cadmium in marine organisms. Experientia 40: 14-23

Ray, S., White, M. (1981). Metallothionein-like protein in lobsters (Homarus americanus). Chemosphere 10: 1205-1213

Renzoni, R. (1982). Mercury and selenium in the Mediterranean Sea. 5th Joint Oceanographic Assembly Abstracts, Vol. I. Department of Fisheries and Oceans, Scientific Information and Publication Branch, Ottawa, p. 53

Roesijadi, G., Hall, R. E. (1981). Characterisation of mercury binding proteins from the gills of marine mussels exposed to mercury. Comp. Biochem. Physiol. 70C: 59-64

Roesijadi, G., Drum, A. S., Bridge, J. R. (1981). Mercury in the mussels of Bellingham Bay, Washington (USA): occurrence of mercury binding proteins. In: Calabresse, A., Vemberg, W., Thurberg, F. P., Vernberg, F. J. (ed.) Biological monitoring of marine pollutants. Academic Press, New York, p. 357-376

Shamberger, R. J. (1981). Selenium in the environment. Sci. Total Environ. 17: 59-74

Sternlieb, I., Goldfischer, S. (1976). Heavy metals and lysosomes. In: Dingle, J. T., Dean, R. T. (ed.) Lysosomes in biology and pathology, Vol. 5. North Holland-American Elsevier, New York, p. 185-197

Taylor, N. S. (1965). Histochemical studies of nephrotoxicity with sublethal doses of mercury in rats. Am. J. Path. 46: $1-21$

Ulmer, D. D. (1970). Effects of metals on protein structure: In: Maniloff, J., Coleman, J. R., Miller, M. W. (ed.) Effects of metals on cells, subcellular elements and macromolecules. Charles C. Thomas Publishers, Springfield, p. 11-35

Verity, M. A., Reith, A. (1967). Effect of mercurial compounds on structure linked latency of lysosomal hydrolases. Biochem. J. 105: 685-690

Watling, H. R., Watling, R. J. (1982). Comparitive effects of metals on the filtering rate of the brown mussel (Perna perna). Bull. environ. Contam. Toxicol. 29: 651-657

Webb, J. L. (1966). Enzyme and metabolic inhibitors, Vol. II. Academic Press, New York, p. 729-985

Webb, M. (1975). The metallothioneins. Trans. biochem. Soc. 3: 632-634 